\title{
Nationalisme, disciplin og folkelighed i 1800-tallets Danmark
}

\section{Af Niels Kayser Nielsen}

Den danske idræt kan siges at tage sin begyndelse i sidste fjerdedel af 1700-tallet - for så vidt som man hermed mener organiserede fysiske aktiviteter og legemsøvelser beregnet for den brede befolkning og ikke kun adelen og borgerskabet. I løbet af 1800-tallet bliver denne brede befolkning takket være nationalismens udbredelse til 'folket'. Men - og det er tesen i denne artikel - det ændrer ikke ved, at ét af de instrumenter, hvorved befolkningen nationalt vækkes og søges løftet i en omfattende civilisatorisk bestræbelse, nemlig idræt og kropsøvelser, har rod den oplyste rationalisme i 1700-tallets sidste fjerdedel. Det er forbindelsen mellem 1700-årenes rationalisme og den folkelige 'almueuddrivelse' i 1800-årene, der er temaet i denne afhandling.

De første initiativer i den retning fandt sted i provinsen i tilslutning til progressive godsejeres virke. Her tænkes primært på brødrene Chr. Ditlev Reventlow og Johan Ludvig Reventlow, som hver især - på henholdsvis Pederstrup på Lolland og Brahetrolleborg på Sydfyn - i løbet af 1780 'erne tog initiativ til de første systematiske legems $\varnothing$ velser for almuen (Kayser Nielsen 1993, 25 ff.). Det skete i inspiration af den tyske filantropiske kropskultur, som de havde stiftet bekendtskab med i deres ungdomsår som elever på Sorø Akademi, hvor Johann Bernhard Basedow, den tyske kropsfilantropis fader, virkede i 1760'erne. Kilderne fortæller, at C. D. Reventlow allerede i 1782 foranstaltede "morsomme Lege" for fæstebønderne på Pederstrup (Reventlow 1902, 70), og at Johan Ludvig Reventlow en søndag kort efter midsommer 1787 foranstaltede danse og lege i slottets have for bønderne og deres børn (Peitersen 1973, 11).

Men påvirkningen fra de tyske filantropiske legemsøvelser indskrænkede sig ikke hertil. Efter at Johan Ludvig Reventlow i 1777 havde erhvervet Brahetrolleborg på Sydfyn, fik han interesse $\mathrm{i}$ at engagere latinskolelæreren Peter Villaume fra Berlin til at forestå gymnastikundervisning for de fremmeligste af godsets bønderbørn. Det lykkedes dog ikke før i 1793.

Denne Villaume var ikke hvem som helst. Reventlow havde fåt fat $\mathrm{i}$ en europæisk kapacitet, som blandt andet havde bidraget til J. H. Campes 16 bind store oplysnings-encyklopædi Revisionsvarket, skrevet i årene 1785-91 (oversat til dansk 1799-1806), med et skrift på et par hundrede 
sider om legems $\emptyset$ velser. Karakteristisk for tidens tankegang var dette skrift for det første rationalistisk præget og kendetegnet ved en udpræget systematik, der dels gjorde rede for de enkelte kropsdele, dels for de enkelte gymnastiske øvelsers særtræk: hver enkelt legemsdel skulle gøres til genstand for en systematisk træning.

For det andet er det karakteristisk, at der blev lagt vægt på moralske forbedringer i retning af "Lidenskabernes Moderation". Kendetegnende er det imidlertid, at vejen hertil gik over "Legemets Opdragelse". Man mente, at den moralske forbedring kun ville batte lidt, hvis ikke opdragelsen var kropsligt forankret, det vil sige gjort til en slags erfaringsmæssig tavs viden. Kun herved opnår erkendelsen den "Kraft, der give dens Lærdomme Eftertryk", skriver Villaume (Villaume 1802, 218).

Det tredje karakteristiske træk ved denne tidlige rationalistiske og filantropiske kropskulturs teorigrundlag var kultiveringstanken. Man udgik fra, at naturen $\mathrm{i}$ forvejen stillede et godt og solidt råmateriale til rådiged, som det så gjaldt om at forbedre. Alene at forlade sig på naturens egen evne til forædling ville være at udlevere sig til et tilfældighedsprincip; i stedet måtte man komme naturen i møde og tilstræbe en udbygning af det, som den selv havde gjort til 'Legemets Dannelse' (Villaume 1802, 193).

Af den grund burde man sørge for at iklæde børnene tøj, som de frit kan bevæge sig i, ligesom man burde opildne til frie, selvvalgte lege for børn. Men ville man for alvor opnå ønskværdige resultater, burde man også lægge sig efter "konstige Øvelser”, dvs. konstruerede systematiske legemsøvelser. Hermed ville man at hjælpe naturen på vej, så der kunne tilvejebringes en naturligt smidig og mådeholden krop. Dette $\emptyset$ nske om forbedring af de naturligt givne kropslige anlæg sigtede dels mod erkendelse, dels mod overordnede perspektiver for legems $\varnothing$ velserne i retning af civilisering og kultivering. Således spillede naturbegrebet direkte og indirekte en stor rolle. Som det karakteristisk hedder hos præsten P. O. Boisen, der blev seminarieforstander på Lolland hos C.D. Reventlow og senere biskop: "Børn ere jo ikke af Naturen onde; men have Anlæg til det Gode" (Boisen 1800, 5).

Villaumes skrift er sammen med J. L. Reventlows Pro Memoria fra 1794 om indretningen af lærerseminarier på et strengt rationalistisk og hierarkisk grundlag (Reventlow 1900, 106) med hovedvægten lagt på orden, systematik og klassifikation, hvor alting skal være på sin "rette plads", den fornemste kilde til belysning af de egentligt filantropisk orienterede legemsøvelser i Danmark. Grundtankerne, som går igen i disse skrifter, er et rationalistisk dannelses- og oplysningsperspektiv, en 
udpræget disciplineringsbestræbelse samt en ordens- og klassifikationstrang. Denne sans for orden drejede sig for Peter Villaume og J. L. Reventlow primært om analytisk kategorisering og hierarkisering, medens den mere jordnære P. O. Boisen ved orden snarere forstod det modsatte af roderi og "Tarvelighed". Sigtet med Villaume og Reventlows værker var givetvis gymnastisk igangsættelse via anvisning på fysiske aktiviteter og legems øvelser, men i grunden var de i lige så høj grad filosofiske værker, som ikke kun havde handlingsanvisninger, men også ræsonnementer og pædagogiske begrundelser for disse for $\emptyset$ je. Hos Boisen gik de humanistiske opdragelsestanker derimod fortrinsvis i praktisk retning. Han var mindre vidtløftig og filosofisk anlagt end de to andre.

Kilderne peger imidlertid også i retning af, at J. L. Reventlow havde nok så nytteorienterede motiver med legemsøvelserne (om ikke andet så som flidspræmie for de elever, der var særligt flittige i godsskolernes undervisning). Fra sin ungdom i Sorø havde han via Basedow kendskab til den Locke'ske materialistiske pædagogik: at sansernes input er grundlaget for den intellektuelle erkendelse, og at der derfor - for at tilsidesætte tilfældighedsfaktoren - kunne være al mulig grund til at sørge for at stimulere sanserne og den kropslige vigør, når det nu drejede sig om at få skabt driftige bønder. Heller ikke Villaume var fremmed for denne tanke. Om forudsætningerne for sjælens dannelse skriver han, at sjælen "faaer sine Ideer, Grunden til alle dens Operationer, allene ved Legemets Hjælp, nemlig igjennem Sandserne" (Villaume 1802, 221). Ønsket om at skabe flittige og "vindskibelige" bønder var med andre ord en væsentlig del af de filosofiske teorier.

\section{Militæer farvning af idratten i København}

Men også i hovedstaden begyndte man i denne periode at interessere sig for systematiske legems øvelser. Toneangivende kredse i København nærede allerede i 1780 'erne interesse for kropslige initiativer med sigte på kropslig civilisering. Man ville det grove og vellystige levned til livs, som hævdedes at dominere blandt den københavnske overklasse, ligesom man ville almuens uregerlighed og plumphed til livs. Lægen Johan Clemens Tode førte an i denne interesse. Han stod for hovedparten af den sundhedsoplysende litteratur på dansk i denne periode og kunne bryste sig af læsere blandt Københavns mest prominente personer - fra kongehuset og de mest betydningsfulde adelsfamilier til de vigtigste repræsentanter for det nye handelsborgerskab (Mellemgaard 1995).

Legemsøvelser diskuteredes mellem andre af tidens spørgsmål sådan- 
ne oplyste steder som i Dreyers Klub og i kredsen omkring Bakkehuset, der begge repræsenterede selskabelige og intellektuelle fora, hvor det progressive borgerskab færdedes med stolthed og glæde, og hvor blandt andet forfatteren Knud Lyhne Rahbek tog aktivt del i den nye sunde friluftsbevægelse. Ønsket om at forme og iscenesætte kroppen var i det hele taget stort i perioden op til ca. 1800. Dette $\emptyset$ nske fremførtes især af civile kredse, domineret af godsejere, teologer og filosoffer, som ikke kun ville disciplinere, men også opdrage kroppen med henblik på en dannelse og forfinelse, som skulle udvikle og styrke sanserne. Dette mål kommer blandt andet til udtryk i tilbøjeligheden til at bruge naturen som ikke kun rekreations-, men også bevægelsesrum.

Længslen efter et mere naturligt liv var stor i disse oplysende og oplyste kredse. Eftersom bylivet måtte gælde for det unaturlige, usunde og uharmoniske, blev om ikke livet på landet, så dog det periodiske liv på landet og et mere naturligt liv i byen et ideal. Den unge kronprins Frederik - den senere Frederik 6. - blev derfor i Struensee-tiden opdraget efter Rousseau'ske principper. Tilsvarende blev Frederiksberg Have som så mange andre parker i samtiden omformet fra den stive, geometriske franske havestil til den følsomme, afvekslende, organiske og romantiske engelske have.

I 1790'erne tager progressive borgerkredse for alvor fat, i form af en egentlig pædagogisering af kroppen. Det sker i såkaldte 'institutter', hvoraf Christianis Institut på Vesterbro fra 1794 er det mest berømte. Det skyldes ikke mindst, at det danner baggrund på Jens Juels maleri Den lobende dreng fra 1799. Med sit portræt af en dreng i puberteten, der løber let og elegant med smidige bevægelser, markerer dette maleri et nyt kropsideal som modsætning til den galante tids stive, næsten geometriske kropsholdning. Ligesom den ydre natur skal omlægges i følsom og mere sensitiv retning, skal også den menneskelige krop gøres smidigere og mere bevægelig.

Den ledende skikkelse inden for idrættens gennembrud i København var V. F. Nachtegall. Han indledte sin gymnastiske løbebane i det institut, som hofpræst Christiani i 1794 havde oprettet på Vesterbro, hvor gymnastiklokalet ifølge Nachtegall dog mere blev brugt til uforpligtende forn $\varnothing j$ jelser end til metodiske legems $\emptyset$ velser. Fra anden side ved vi, at der dog var tale om løb og badning samt almindelig bevægelsesglæde, sådan som det fremgår af Jens Juels billede af den løbende dreng, der, som Hans Dragehjelm har sandsynliggjort, var en af Christianis elever (Dragehjelm 1933). På Jens Juels maleri ser man da også Christianis imposante institut i baggrunden (Mellemgaard og Kayser Nielsen 1996, 
56).

I 1799 blev Nachtegall ansat i det Schouboe'ske Institut, der var blevet oprettet året før som en konkurrent til Christianis Institut. Men han havde mere ambitiøse planer. Ligeledes i 1799 oprettede han Gymnastisk Selskab i København, hvor der kom studerende og unge handlende, og sidst på året tog han så skridtet fuldt ud og dannede sit eget gymnastikinstitut. Nu var han klar til at gå i felten. Straks fik instituttet 5 elever, og inden årets udgang var man oppe på 25. I en håndskrevet fremstilling fra 1840 af gymnastikkens begyndelse i København anfører han endog, at antallet var på "meer end 150 Drenge og Ynglinge" (Nachtegall 1840, 3). Hvordan det nu måtte forholde sig, er det givet, at Nachtegalls initiativer allerede fra starten $n \varnothing d$ fremme af, at stærke politiske og kulturpolitiske kræfter allerede fra starten sendte deres børn til hans institut (Kayser Nielsen 1995).

Det er derfor ikke for meget sagt, at Nachtegall efter århundredskiftet $1800 \mathrm{kom}$ til at tegne billedet af kropskulturens og idrættens historie. Hans institut-ildhu omkring 1800 vidner herom, såvel som hans flittige publiceringsvirksomhed, der tog sin begyndelse i 1805. Karakteristisk for den sidste er imidlertid, at han ikke er nær så interesseret i de kropsfilosofiske spørgsmål som de kredse, der var toneangivende i 1790'erne. Det er ligeledes kendetegnende, at hvor Reventlow'erne søgte at fremme legemsøvelserne via seminarier og landsbyskoler, det vil sige via de kanaler, som det civile samfund tilvejebragte, søgte Nachtegall - med eller mod sin vilje - mere de militære, og dermed de statslige, kanaler. Måske havde han en fornemmelse af, at de åbnede flere muligheder for succes end seminarievejen. Under alle omstændigheder drejede det nære samarbejde mellem Nachtegall og kronprins Frederik kropskulturen væk fra det civile samfund og over i de statslige myndigheders regi. I 1834, hvor han udsendte sin sidste trykte bog Larebog $i$ Gymnastik til Brug for de laerde Skoler i Danmark, er der intet spor af dannelsesovervejelser, endsige pædagogiske tanker. Karakteristisk nok skriver han om klatring, at det kan være godt mod svimmelhed! Så langt var det da kommet med de dannelsesmæssige visioner i forhold til kroppen i en bog, der i øvrigt bruger det meste af pladsen for at gøre rede for svømning, eksercits og lignende. Samme tanker går igen i Nachtegalls håndskrevne fremstilling fra 1840 (beroende i Det Kongelige Bibliotek), som med hovedvægten lagt på årene efter 1830 i øvrigt domineres af opgørelser over, hvor mange soldater og civile der år for år havde deltaget $\mathrm{i}$ hans idrætsundervisning i København. 
Hans første bog Instruction i Gymnastikken for de Larere som ere ansatte ved Kavalleriets og Infanteriets Underofficer og Exerceerskoler udkom i 1805 og bærer i sin pædagogiske form, der består af vekslen mellem spørgsmål og svar, endnu præg af oplysningstidens klassiske matrice for sådanne lærebøger. Indholdet er derimod ikke synderligt præget af oplysningstanker, men henvender sig udelukkende til "Krigere" og negligerer helt oplysningstidens didaktiske formål.

Det er i den forbindelse megetsigende, at Nachtegall i sine to gymnastikhistoriske arbejder fra alderdomsårene ikke med et ord nævner Reventlow'erne og deres foregangsarbejde. Han omtaler direkte Vesterborg og Skaarup seminarier og deres forstanderes opfattelse, at gymnastisk viden er noget, enhver skolelærer bør have kendskab til, og så var C. D. Reventlow ellers Vesterborg Seminariums 'fader'. Han påpeger ligeledes, at det er inspektør Jacob Saxtorphs fortjeneste, at Blågård Seminarium var det første sted, der "forenede methodisk Underviisning i Legems $\varnothing$ velser med de $\varnothing$ vrige Læregjendstande" (Nachtegall 1831, 6) og nævner ikke med en stavelse, at J. L. Reventlow havde haft en væsentlig indflydelse på oprettelsen af Blågårds Seminarium i 1792. Endvidere nævnes, at "Grev Holstein til Holsteinborg var den første Godsejer i Riget, som indførte gymnastiske Øvelser i sine Skoler" (Nachtegall 1831, 16). Men ikke et ord om Johan Ludvig og Christian Ditlev Reventlow. Og det til trods for, at det allerede i skolereglementet af 1791 for C. D. Reventlows gods Christianssæde hedder, at legems $\emptyset$ velser for $\varnothing$ ger legemets styrke og behændighed, og at de derfor ikke bør fors $\emptyset$ mmes i skolerne (Larsen 1913, 5), og at der siden 1801, ledet af pastor P. O. Boisen som Reventlows forlængede arm, havde været dyrket forskellige former for legems $\varnothing v e l s e r$, såsom roning, svømning og spring med stokke ved Vesterborg seminarium (Holgaard Rasmussen 1979, 18).

Bag denne konsekvente negligering af den ældste filantropiske gymnastikfordring ligger formodentlig ikke kun taktiske overvejelser og $\emptyset$ nsket om at gøre sig selv mere betydningsfuld, men også en fundamentalt anden opfattelse af, hvad der var 'rigtige' legems øvelser. Der er tale om et holdningsskift i forhold til tidligere. Den mere sofistikerede opfattelse af forholdet mellem krop og sjæl fra Villaumes dage er nu erstattet af en en robust kropsdyrkelse. Samspillet mellem krop og sjæl er her reduceret til kausalitet. I princippet er der derfor intet til hinder for at udvikle de kropslige organer maksimalt. Nachtegall foranstaltede da også et væld af svømmekonkurrencer i København og ivrede for en præstationsmaksimering.

I det hele taget er det høje idealistiske sigte fra før 1800 nu ændret i 
anden retning. Dels i retning af kortsigtet nytteorientering, dels i retning af storslåede helteperspektiver, som nu i takt med den nye nationalistiske tidsånd kom mere og mere i focus. I 1802 havde Laurids Engelstoft, der også tilhørte kredsen omkring Nachtegall, således skrevet en afhandling $\mathrm{i}$ tidsskriftet Skandinavisk Museum om vikingetidens idrætter med be-

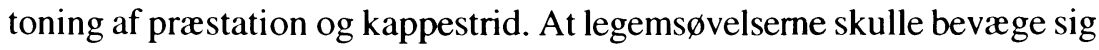
i den retning, havde Reventlow-brødrene ikke drømt om. Dannelsesperspektivet havde tabt $\mathrm{i}$ betydning til fordel for en nationalistisk farvet præstationsorientering, og det gamle 'ædle' filantropiske perspektiv blev omkring 1810 anfægtet fra flere sider (Kayser Nielsen 1993: 63 ff.).

Nachtegall var ikke den eneste, som skrev lærebøger i gymnastik og legems $\emptyset$ velser. Også hans kollega P. H. Mønster, inspektøren fra Efterslægtens Skole, gav sig af med den slags. Hans store værk Om Gymnastikkens Anvendelse paa Ungdommens Opdragelse fra 1804 adskiller sig til gengæld meget fra de Nachtegall'ske intentioner. Dette værk er helt i den Villaume-Reventlow'ske ånd og bærer i høj grad præg af filantropiske filosofiske dannelsesidealer. Imidlertid kommer bogen i kun ringe udstrækning ind på praktiske ting $\mathrm{i}$ forbindelse med undervisningen. Den drejer sig mere om opdragelse end om teknik. Det samme gælder hans svømmebog fra 1803. I den nævner han ikke militæret som baggrund for idræt, men hævder i stedet, at fysisk kraft fremmes, hvis man følger "saavel Lægens som Philosophens som Opdragerens forenede Raad" (Mønster 1803, 4). Samme Mønster tog i 1805 sin afsked fra Efterslægtsselskabets Realskole. Han blev præst i Gyrstinge på Midtsjælland og sørgede her for, at der blev undervist i gymnastik i sognets skoler.

\section{Den filantropiske idrats nederlag}

Og her er det så, at linjerne trækkes klart op: I provinsen, med almueskolevæsenet som forum, er de humanistiske dannelsesidealer vedrørende kroppen mere fremherskende end i hovedstaden, hvor der i militært regi lægges vægt på kropslig teknik og færdighed. Det er ligeledes i provinsens civilt oprettede lærerseminarier i for eksempel Vesterborg præstegårdsseminarium og på Brahetrolleborg, disse filantropiske idealer holdes $\mathrm{i}$ hævd. Her ser man et mere alment sigte end blot kroppens fysiske beskaffenhed i en snæver mål-middel tænkning, ligesom man ikke holdt sig til gymnastik, svømning og våben øvelser, men også havde frie lege $\mathbf{i}$ tankerne. På Blågårds Seminarium begyndte Nachtegall i 1805 at holde forelæsninger over gymnastikkens teori og metodik. Her udmærkede 
eleverne sig, ifølge ham, især i "Svømning og militaire Øvelser" (Nachtegall 1831: 9). Man aner med andre ord en tydelig forskel mellem de statsligt-militære initiativer og det civile samfunds skolebaserede opfattelse. Nachtegall selv havde ikke noget imod at uddanne lærere til gymnastik i landsbyskolerne, men de skulle helst være uddannet i et regi, som han havde hånd $\mathrm{i}$ hanke med. Det samme gjaldt Frederik 6., som i 1808 gav civile adgang til fri undervisning ved det militære gymnastikinstitut (Nachtegall 1931, 12).

Således tabte den civile og lokalt prægede kropskultur med vægten lagt på kropslig dannelse og forfinelse kampen med militæret om udformningen af gymnastikken. Helt frem til 1898 var det militære gymnastikinstitut det eneste sted, hvor der blev uddannet gymnastiklærere til de offentlige skoler i Danmark. Og de tanker, der lå til grund for gymnastikkens introduktion i skoleloven af 1814 , var et barn af den militære udgave af kropsopfattelsen. Brahetrolleborg Seminarium blev nedlagt, og på Vesterborg Seminarium var man heller ikke i stand til at holde den filantropiske dannelsestænkning højt.

Indførelsen fra oven af en militært farvet gymnastik i de danske almueskoler bidrog sandsynligvis væsentligt til at etablere den danske dobbelt-offentlighed, der skulle blive så karakteristisk for det danske samfund gennem hele 1800-tallet, og som i virkeligheden først blev overvundet med det store forlig mellem by og land, der i såvel Danmark som i Sverige, Norge og Finland fandt sted i 1930'erne på både det politiske og det sociale og kulturelle område og endeligt kodificeret i kraft af kommunalreformen 1970. Som Erik Nørr har påvist, udspillede denne konflikt mellem lokalforvaltning og statsforvaltning sig ikke mindst på skoleområdet. Konflikten tog især til efter indførelsen af sogneforstanderskabet, det vil sige sognerådene, fra 1842, hvor de nærige gårdmænd i sognerådene havde ondt ved at forliges med de centrale uddannelsesintentioner (Nørr 1994, 31 ff.). Der er dog ingen tvivl om, at kimen hertil var lagt tidligere, nemlig dels i de begivenheder i almindelighed, som gik forud for skoleloven af 1814 og her de kropskulturelle tvangsinitiativer i særdeleshed, dels i selve den juridisk-administrative forvaltning af 1814-skoleloven, også på gymnastikkens område. Vi har her et sjældent tydeligt eksempel på, at idrætshistorien udmærket kan bidrage til belysning af den 'store' historie.

Almueskolens gymnastikundervisning blev - takket være især Nachtegalls og Frederik 6.s ihærdige indsats - formet ud fra militære retningslinjer, medens tilsynet med skolestyret var lagt i hænderne på gejstligheden: biskoppen øverst og dernæst en skolekommission med 
sognepræsten som omdrejningspunkt. Disse havde som hovedregel ingen eller kun ringe forståelse for idræt og var derfor ikke i stand til at byde den militært tænkte gymnastik trods. I takt med, at de filantropiskhumanistiske dannelsestanker fra århundredskiftet 1800 mere og mere fortonede sig i tågerne, blev mere og mere derfor lagt i hænderne på den enkelte lærer. For at have hånd $\mathrm{i}$ hanke med sagerne indførte man fra Kulturministeriets side en særlig faglig inspektion for gymnastikkens vedkommende som sikkerhedsgarant. Denne gymnastikinspektør skulle blandt andet udtale sig om de indberetninger, der årligt blev indsendt fra provstierne (Nørr 1994, 363 f.).

Uheldigvis ved vi imidlertid så godt som intet om, hvorledes almueskolens gymnastikundervisning rent faktisk foregik i årene frem til 1848, hvor gymnastikinspektionen kommer på banen. Men enkelte lokalhistoriske nedslag, for eksempel fra Hover i Vestjylland, vidner om, at der var store forskelle fra sogn til sogn; betinget af de pågældende læreres evner og nidkærhed (Kaae 1998, 224 ff). Alene indberetningerne vedrørende antallet af kapable lærere synes at være behæftet med stor usikkerhed. Her forestår en stor idrætshistorisk (og skolehistorisk) forskningsopgave. Måske har lærernes manglende gymnastiske kyndighed resulteret i mere pjank og sjov, end man umiddelbart skulle tro. Eller måske har den samme mangel på kyndighed som resultat netop haft, at lærerne så har holdt sig til det mest simple: at eksercere og kommandere.

I så fald har man kunnet hente opskrifterne herpå hos Nachtegall, hvor der er masser af anvisninger på den slags. Skal man desuden dømme efter undervisningsformen i den såkaldte indbyrdes undervisning, som både Nachtegall og Frederik 6. havde forkærlighed for, da der kunne "undervises paa eengang i en Afdelings eller Skoles forskellige Nummere" (Nachtegall 1828), har det ikke skortet på marcheren i de skoler, hvor denne undervisningsform blev appliceret (Høybye-Nielsen 1969). Det er vel ikke utænkeligt, at der har været en vis lighed mellem denne undervisnings generelle form og gymnastikundervisningen i særdeleshed; især når det tages i betragtning, at Nachtegall i sin gymnastiklærebog fra 1828 også anbefalede den indbyrdes undervisning for gymnastikkens vedkommende.

Kontrafaktisk kan man spørge, hvad der var sket med bøndernes modvilje mod legemsøvelserne, hvis det havde været en pædagogik af filantropisk observans, der var kommet til at præge gymnastikken i de danske almueskoler fra 1814. Svaret herpå kan ikke gives, men der er grund til at formode, at det så havde været langt vanskeligere for de grundtvigianske kredse med deres 'lysere' syn på kroppen at bryde igen- 
nem senere $\mathrm{i}$ århundredet, da de introducerede den svenske Linggymnastik med dens filantropiske pædagogiske idealer. Nu fremstår historien, som om det var med dem, kampen mellem den lokalt tilrettelagte skole og den 'sorte' statsskole brød igennem. I virkeligheden skete det langt tidligere. Som på andre områder sparkede grundtvigianerne en historisk åben dør ind, ligesom de trak veksler på den rationalistiske oplysningstids kropssyn. Som den finske historiker Henrik Stenius har påpeget, har den særegne danske dobbelt-organisering af uddannelses- og oplysningsinitiativer ikke sin rod i den grundtvigianske filosofi (Stenius 1993, 193). Den går længere tilbage, nemlig til forvaltningen af de danske rationalistiske oplysningsinitiativer. Her spillede Nachtegall og Frederik 6. en væsentlig rolle. Dem har den grundvigianske tradition - på godt og ondt - meget at takke for. Det var primært på grund af dem, at den danske almuebefolkning via skolens gymnastikundervisning fik indlejret spor i kroppen af militær eksercits og derved installeret en tavs viden om statsmagtens syn på, hvad en krop er.

Denne tavse viden skulle i løbet af 1800-tallet få store historiske følger for det danske samfund: dels flyttede nissen med i form af kropslige spor af disciplin, dels ønskede man at opponere og selv have hånd i hanke. Den dobbelthed kom tydeligst til udtryk i oprettelsen af skyttebevægelsen.

\section{Skyttebevagelsen: folkelig og national dannelse}

Skyttebevægelsen i Danmark tager sin begyndelse i 1861. Inspirationen kommer umiddelbart fra England, men idégrundlaget er lagt allerede i årene efter Treårskrigen 1848-50. Inspireret af sejren over slesvigholstenerne og af den nationale vækkelse, der gjorde sig gældende i tilslutning til Juni-grundlovens indførelse i 1849 og den national-liberale politik i disse år, opstod der i borgerlige kredse en øget værnevilje og en bevidsthed om, at Danmark var beboet af et folk og ikke kun kongens patriotiske undersåtter. H. V. Bissens Landsoldat i Fredericia er det synlige emblem for dette folkeligt-nationale gennembrud.

I september 1848 indførtes nemlig almindelig og lige værnepligt, og herfra var der ikke langt til en forestilling om oprettelsen af frivillige hjælpekorps, som kunne træde til og støtte landets $\emptyset$ vrige forsvar. Ganske vist kan man i 1850 'erne i debatterne i Rigsdagen konstatere en vis modvilje mod en sådan tanke, især fra landboside, men de nationalliberale borgerlige kredse har på dette tidspunkt fortsat så meget vind $\mathrm{i}$ sejlene, at der er almindelig positiv stemning for en supplerende folke- 
væbning, i de toneangivende kredse.

Den udløsende faktor er en artikel i Carl Plougs nationalliberale dagblad Foedrelandet den 19. januar 1861 af artillerikaptajn Hans Peter Valdemar Mønster om de engelske frivillige skytteforeninger, der havde til formål at udbrede kendskabet til skydning og våbenbrug gennem aktive øvelser. De var et eksempel til efterfølgelse i Danmark, mente Mønster. Artiklen havde som medunderskrivere en række kendte personer fra militæret, universitetet, erhvervslivet, bladverdenen og litteraturen, herunder Carl Ploug selv. Det lå derfor lige for, at Mønster rettede henvendelse til offentligheden om støtte til idéen. Her viste det sig, at der var stor interesse, og i løbet af 1861 nød tanken så meget fremme både i byerne og på landet, at de første skytteforeninger så dagens lys allerede i løbet af de første måneder samme år.

Udslaggivende var ikke mindst, at foretagendet allerede fra starten blev lagt $i$ en fast organisatorisk ramme med en central styring allerede fra februar 1861 i form af Centralkomitéen for Oprettelse af Skytteforeninger, samt at sagen nød økonomisk godt af den offentlige interesse (Kayser Nielsen 1989a og 1989b). Den, som for alvor tog sagen op, var amtmanden i Vejle, Orla Lehmann, som mente, at skyttesagen skulle på finansloven. Denne opbakning blev ikke ringere af, at Lehmann i september måned 1861 overtog pladsen som indenrigsminister efter D.G. Monrad.

Helt konkret havde skyttebevægelsen tre problemer, som skulle løses. Der var for det første spørgsmålet om skydeplads. I København blev det løst ved, at krigsminister Thestrup bevilgede skytterne lov til at benytte hærens skydebaner på Vesterbro, dér hvor nu Halmtorvet og Kødbyen ligger. Økonomisk skulle skyttebevægelsen og militæret stå halv skade. Andre steder overlod interesserede jordejere deres marker til skydeøvelserne.

Et andet problem udgjorde instruktionen, som imidlertid - imponerende hurtigt - blev afhjulpet ved at der allerede sommeren 1861 lå en instruks for våbenbrug og skydeøvelser klar. Også den fik økonomisk st $\varnothing t t e$ fra oven, idet krigsministeriet efter anmodning fra skyttebevægelsens Centralkomité ydede 100 rigsdaler, så den kunne sendes ud landet over.

Og så var der endelig spørgsmålet om geværer og ammunition. Da Mønster ikke selv forventede støtte hertil fra statsmagtens side, rettede han i stedet henvendelse til kommunalbestyrelser, skydelaug og de største jordbesiddere. Det blev imidlertid ikke den store succes, idet man kun i Vejle, Silkeborg og Middelfart reagerede positivt (Krogh 1911, 57). I 
Vejle donerede tre herrer fra skyttelauget et bel $\varnothing b$, der svarede til indk $\varnothing b$ af 8-10 rifler (Jensen 1968, 7). Imidlertid gik staten også på dette felt ind med aktiv opbakning.

Centralkomitéen s $\varnothing$ gte i november 1861 Indenrigsministeriet om st $\varnothing$ tte med et bel $\varnothing$ b på 2000 rigsdaler. Det blev bevilget allerede i januar 1862, mod at skyttebevægelsen selv bidrog med et lignende beløb, og mod at ministeriet blev underrettet om, hvilke geværer man ønskede at indkøbe. Fra ministeriets side var man nemlig interesseret $i$, at man erhvervede de moderne belgiske miniérifler i stedet for de gammeldags taprifler, som hæren brugte. Hertil kommer, at indenrigsminister Lehmann udsender et cirkulære til amtmændene om at fremme skyttesagen lokalt, og efter en rykker herom i 1863 sker der så for alvor noget i sagen, idet der i løbet af dette år oprettes skytteforeninger i over cirka 100 sogne landet over. Indenrigsministeriets aktive politik gav nu resultat. Statsmagten viste sig at være den afgørende drivkraft bag skyttesagens udbredelse.

Vejle Amt blev ét af de første skytteamter. Det kan næppe overraske, når man tager kombinationen af Treårskrigen ("I Natten klam og kold, / Bag Fredericia Vold") og garnisonen i Fredericia. I Vejle Amts landsogne foregik den første skytteorganisering i henholdsvis Jelling og Vejlby sogn, begge steder så tidligt som i 1863 (Jensen 1968, 8). Den store betydning for krigen i 1864 fik skyttebevægelsen nu ikke. I Jelling sørgede skytteforeningens formand, pastor Svendsen, for at grave foreningens geværer ned, så at de ikke faldt i tyskernes hænder (Jensen 1968, 8). Ikke desto mindre fortsatte entusiasmen, og i 1867 havde følgende sogne i nærheden af Fredericia ud over Vejlby dannet hver sin kreds: Errits $\varnothing$, Gårslev, Bredstrup, Taulov og Eltang (Svendsen 1943, 6).

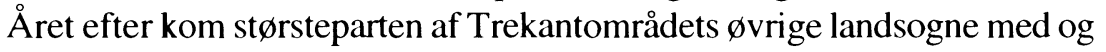
fik oprettet skytteforeninger, som dog kun eksisterede et par år (Kayser Nielsen 1997).

Men ellers er 1869 det store gennembrudsår for oprettelse af skytteforeninger landet over. Her må man have i tankerne, at nederlaget til tyskerne i 1864 havde været dyrt. Økonomisk set havde krigen kostet et beløb svarende til 60 millioner kroner [kronen indførtes i 1875 til en værdi af $1 / 2$ rigsdaler]. Der var faldet over 3.000 mand, man havde afstået de tre hertugdømmer, og mere end 200.000 dansksindede var blevet ladt tilbage syd for grænsen ved Kongeåen. Derfor lurede tanken om en revanche, og ikke så få faner landet over bærer fra den tid påskriften "Sønderjylland vundet, det er Kampens Maal" eller - med et citat fra Fr. Paludan-Müllers sang Brat af Slaget rammet: "Slesvigs Land genvundet! / Det er Kampens Maal." Denne tanke fik ikke mindst næring af 
uenigheden mellem de to magter Tyskland og Østrig, som havde besejret Danmark i 1864, og af den spændte relation mellem Tyskland og Frankrig, som man håbede meget på. Et synligt bevis herpå var hærloven af 1867, som krigsminister Raasløff fik gennemført. Den skulle sikre en kraftig feltstyrke, som kunne hjælpe en tyskfjendtlig stormagt i tilfælde af krig. Da flere politikere og kulturpersonligheder, herunder N. F. S. Grundtvig, nærede modvilje mod den tvungne værnepligt, men gerne så et stærkt forsvar, blev den frivillige skyttebevægelse en udvej.

Denne oprustning samt de revanchistiske drømme gav skyttebevægelsen vind i sejlene. Medvirkende hertil var formodentlig også en udvidelse af repertoiret. I de første år havde der ud over skydning været eksercits og marchøvelser på programmet. Det skete ikke mindst, når folk skulle gå til skydepladsen og så lige så godt kunne udnytte tiden 'fornuftigt'. Dette tiltalte imidlertid ikke bondebefolkningen, idet det gav mindelser om den forhadte eksercits, som man blev udkommanderet til at tage del i én gang om måneden bag kirken (Holmgaard 1986).

Det er derfor næppe overraskende, at eksercitsen på et tidligt tidspunkt blev suppleret med mindre martialske gymnastiske $\emptyset$ velser og andre former for legems øvelser. Med andre ord havde skyttebevægelsen - som noget ellers ofte overset - næsten fra sin start almen idræt med som aktivitet. Det kan ud fra kildematerialet være svært at danne sig et indtryk af disse aktiviteters art, men fast står, at Vejle Amts Skytteforenings forretningsudvalg i 1868 udsendte en skrivelse til de lokale skyttekredse om, at der skulle foretages $\emptyset$ velser i skydning, gymnastik og eksercits (i nævnte rækkefølge). For gymnastikkens vedkommende anbefalede man træning i "Gang- og Løbemaaderne" samt højde- og længdespring, spring over buk og sjipning (Jensen 1968), det vil sige en kombination af atletik og gymnastik.

Ved øvelserne i gymnastik fik man et godt grundlag med den Haandbog i Gymnastik for Delingsformand ved Amts-Skytteforeningerne, som premierløjtnant V. la Cour havde udarbejdet, og som Krigsministeriet i 1869 bevilgede 200 rigsdaler til. Statens støtte til idrætsbevægelsen gik hermed ind i en ny fase. Man støttede nu ikke kun skydningen, men også gymnastikken og instruktørvirket. Og sagen vandt geh $\varnothing$ r: I Fredericia blev der sidst i 1870'erne oprettet en gymnastikskole for ungdommen i alderen 10-15 år, som $\varnothing$ vede to gange to timer ugentligt. Den fik hurtigt over 100 elever, som blev trænet af to premierløjtnanter fra den lokale garnison (Jensen 1968, 14). Denne udvikling var ikke enestående.

Gymnastikken slog nu mere og mere an, og fra omkring 1880 dyrkede 
man mange steder udelukkende gymnastik (Gjøde Nielsen 1994, 34 f.). I de brede folkelige kredse havde man mere brug for gymnastik end for eksercits. Gymnastikken var et velegnet middel til at vise et disciplineret og kontrolleret legeme, der ikke havde hverken almuens trællekår eller uregerlige tøjlesløshed som kendetegn, men derimod den ranke ryg. Den vidnede om, at man kunne styre sig selv og sin krop - og dermed også, så småt, styre samfundet. Gymnastikken blev både et tegn på og et middel til folkelig dannelse. Den nye 'svenske' gymnastik blev grundtvigianernes adelsmærke. Den drejede sig ikke om præstation og akrobatik-lignende kropsudfoldelse, men om højnelse af såvel kroppens udtrykskraft som dens funktionsduelighed. Som led heri og i kraft af den nationale baggrund så det civile samfunds foreningsliv intet odiøst $\mathrm{i}$ at modtage statslig støtte. Den nationale kontekst leverede legitimiteten bag en harmonisering af relationen mellem stat og civilsamfund.

Støtten til skytte- og gymnastikbevægelsen fortsatte gennem de resterende tiår af 1800-tallet, det vil sige også i de turbulente provisorieår i 1880 'erne. I begyndelsen af 1880 'erne var statens tilskud til skytteforeningerne oppe på $20.000 \mathrm{kr}$. årligt, og dette beløb blev dernæst hævet, således at det i 1885 var oppe på 35.000 kr. (Kayser Nielsen 1989b, 29). Det beløb er bemærkelsesværdigt, idet det uddeltes samme år, som Venstrefolkene erobrede magten i skyttebevægelsens $\varnothing$ verste organ, den tidligere Centralkomité, der siden 1871 bar betegnelsen Overbestyrelsen, og som indtil da havde været ledet af officerer. Denne blev med andre ord ledet af en ny, grundtvigiansk bestyrelse, hvor der ganske vist sad et par Højre-officerer som 'gidsler'. Det ændrede ikke ved støtten. Myten om den 'onde' Estrup-regerings rabiate forfølgelse af Venstrefolk og højskoletilhængere gælder ikke på dette område.

Det gjorde den heller ikke året efter, hvor skyttebevægelsen blev sprængt. Årsagen hertil var den politisering, som udsprang af riffelprovisoriet og mundkurvscirkulæret. Disse tiltag var en reaktion mod de selvbestaltede riffelforeninger, der blev dannet midt i 1880'erne som reaktion mod Estrups politik. Riffelprovisoriet forbød indførsel, anskaffelse, uddeling og $\emptyset$ velse i betjening af rifler, medens mundkurvscirkulæret gav hjemmel til afskedigelse af skolelærere, som var aktive i riffelforeningerne. Ligeledes indebar riffelprovisoriet, at skytteforeningerne skulle indhente amtmandens tilladelse til at udøve skyttevirksomhed. Alle disse initiativer blev mødt med fortørnelse og bitterhed, og i midten af 1880'erne var den politiske situation spændt. Denne situation kulminerede den 6. september 1886 med det berømte slag på Brønderslev Marked, hvor en folkemængde gik til angreb på 
Estrups gendarmer. At dette angreb dog mere var et resultat af almindelig markedstummel end egentlig politisk bevidsthed, som en nyere lokalhistorisk studie har dokumenteret, er så en anden sag (Pedersen og Kjeldsen 1993).

I Vejle Amt fik sagen både lokale og landsdækkende konsekvenser. Lokalt gav påbuddet om, at skytteforeningerne skulle have amtmandens tilladelse til at skyde, lejlighed til en politisk manifestation. Vejle Amts Skytteforening havde nemlig i sine rækker otte foreninger i den vestlige del af amtet, som formelt tilhørte Ribe Amt. Disse otte foreninger fik ikke tilladelse til at skyde af amtmanden i Ribe, hvorefter foreningen i protest indstillede al skyttevirksomhed. Det betød, at tre af bestyrelsesmedlemmerne, alle officerer med Højre-sympatier, nedlagde deres mandater (Jensen 1968, 16).

Sagen blev yderligere dramatisk og fik landsdækkende konsekvenser, da en række skyttekredse i Vejle Amt deltog i en fest i Kolding for Venstres leder Chresten Berg, der netop var blevet løsladt fra et fængselsophold som følge af riffelrøret. Højrefolkene i Overbestyrelsen ville give disse skytter en reprimande, hvilket ikke blev til noget som følge af Venstrefolkenes majoritet, hvorefter Højrefolkene meldte sig ud. De blev fulgt af en række amtsskyttekredse, og resultatet blev, at der fra $1886 \mathrm{var}$ to skytteforeninger. Det ændrede ikke ved statsstøtten: både den gamle, som var ledet af højskole- og Venstrefolk, og den nye Højre-dominerede fik del i støtten. De $34.000 \mathrm{kr}$. blev fordelt med to tredjedele til Venstrefløjen og en tredjedel til Højrefløjen. Skyttebevægelsen og dermed den organiserede idræt $\mathrm{i}$ form af gymnastik blev opfattet som et nationalt anliggende, og hensynet hertil stod øjensynligt over partimæssige konflikter. I 1893 blev konflikten mellem Venstre og Højre da også bilagt. Det skete ikke mindst takket være de grundtvigianske højskolekredses lobby-arbejde. I grundtvigianske kredse havde man ikke interesse i en sprængning af det folkelige arbejde, og allerede i 1880'erne havde man med blandt andre Ludvig Schrøder i spidsen sørget for, at de mest rabiate riffelfolk i ledelsen af Venstres skyttebevægelse blev udskiftet ikke. Bilæggelsen af striden i 1893 medførte, at skytte- og gymnastiksagen straks fik den statslige bevilling øget til 40.000 kr. årligt (Kayser Nielsen 1989, 31).

Dette beløb blev øremærket, således at der skulle gå $8.000 \mathrm{kr}$. til rifler, $20.000 \mathrm{kr}$. til ammunition, medens de resterende $12.000 \mathrm{kr}$. skulle tilfalde gymnastikken, med $2.500 \mathrm{kr}$. til uddannelse af lærere. Denne sidste post steg herefter kraftigt, således at man i 1903 var oppe på 10.000 kr. til dette formål. 
Det er i den forbindelse ikke uinteressant at hæfte sig ved, at den anden type idræt, nemlig konkurrenceidrætten med vægten lagt på boldspil, atletik og vandsportsgrene såsom sejlads og roning, ikke fik en tilsvarende opbakning. Ganske vist blev den første internationale Gymnastik- og Idrætsfest i København i 1898, hvori der ud over skytter og gymnaster også deltog brydere, boksere samt cricket- og fodboldspillere, tildelt $10.000 \mathrm{kr}$. på finansloven $1898 / 99$, ligesom man fik 4.000 kr. af Københavns kommune (Hansen 1995, 61). Det var første gang, der blev uddelt st $\varnothing t t e$ til anden idræt end skydning og gymnastik, og derefter skete der ikke noget før i 1903, hvor Dansk Idræts-Forbund (DIF), som var stiftet i 1896, efter flere forgæeves henvendelser fik tildelt $3.000 \mathrm{kr}$. af statsmagten, til trods for at der - ud fra et forsigtigt skøn - var omkring 250 sportsklubber landet over på dette tidspunkt (Jørgensen 1995a, 83). Og statens støtte til denne del af idrætsverdenen stod ikke mål med støtten til skydning og gymnastik. Således udgjorde statstilskuddet til DIF i 1938 kun cirka $35.000 \mathrm{kr}$., det vil sige mindre end det beløb, som Skytte- og Gymnastikbevægelsen blev tilført i 1893. Herefter steg støtten imidlertid voldsomt, idet DIF i 1945 kunne påregne et statstilskud, der var det tredobbelte af 1938-beløbet.

Sammenlagt tegner der 'sig imidlertid et tydeligt billede fra $1861 \mathrm{og}$ helt op til 2. verdenskrig: det offentlige nærede absolut størst interesse for skyttesagen og gymnastikken, medens sportsbevægelsen i langt højere grad må klare sig selv.

Denne skævhed kunne imidlertid næppe vække megen forargelse i samtiden. Det var usikkert, hvad den moderne sport repræsenterede. Mange anså den for at være et tilfældigt modelune, iværksat af umodne lømler, medens skytte- og gymnastiksagen blev opfattet som yderst seriøs, for så vidt som den både var nationalt orienteret og del af en folkelig dannelse og civilisering, ligesom den blev anset for at være karakterdannende. Den havde desuden partipolitisk opbakning. I Højre så man med milde øjne på især skydningen, medens Venstre primært var positivt stemt over for gymnastikken, der i form af den såkaldte 'svenske' gymnastik fremstod som en politisk-symbolsk repræsentation for landbobefolkningen. Tilsvarende viste skyttebevægelsen sig også i mødekommende over for statsmagten. I 1901 fremsatte Vejle Amts Skytteforening således det forslag, at veluddannede skytteforeningsmedlemmer, efter aflæggelse af en række prøver, kunne gøre tjeneste i militæret som såkaldt kvalificerede værnepligtige. Hermed ville man slå to fluer med ét smæk: forkorte tjenestetiden for disse medlemmer og aflaste militærets uddannelse af soldaterne. Over for en kropskultur med 
den slags politisk-kulturel slagkraft virkede sporten som dels et byfænomen, dels en vildført ungdoms 'abekattestreger'.

\section{Afslutning}

Kroppen er hjemstedet for smerte, afretning og ensretning, men også sædet for lyst, velbehag og velvære. Kroppen er både universel og privat.

Af den grund kan det være overraskende at konstatere, at kroppen ikke fylder meget i de danske kulturhistorier, der behandler 1800-tallet og det åndelige klima i dette århundrede. Det hører til undtagelserne, at kroppen overhovedet tematiseres i den slags værker. Det er beklageligt, for så vidt som kroppen i mange henseende stod i centrum for det disciplinerings- og civiliseringsforehavende, der dels fra statens side, dels i det civile samfunds regi havde så stor betydning i 1800-tallet. Idrætten og kropskulturen var et vigtigt område for ikke mindst det grundtvigianske folkelige arbejde med dets bestræbelse på at forene det demokratiske og det nationale i rammen af en folkelighed, der inviterede til enighed snarere end konflikt. Som led i denne bestræbelse på en folkelig konsensusdannelse spillede kroppens dannelse en væsentlig rolle (Kayser Nielsen 2003).

Formålet med denne artikel har da været at vise, at forskning i kroppens kulturhistorie ud over at have værdi i sig selv er interessant derved, at den kan komplettere og nuancere den 'store' kulturhistorie. Det danske samfunds udvikling gennem 1800-tallet var kendetegnet ved den kombination af disciplin, dannelse og kropslig frigørelse, som blev indført i slutningen af 1700-tallet. Foreningen af national samfundsmæssighed og indvidualiseringsproces havde langt hen kropslige erfaringer af både tvang og kontrolleret lyst som omdrejningspunkt. Grundtvigianernes bidrag hertil var dels at bygge videre på de filantropiske idealer fra 1700-årene, dels at investere disse i en folkelig dannelsesbestræbelse, der knyttede stat og civilsamfund sammen. Af disse grunde er forskning i kroppens kulturhistorie et både interessant og givtigt felt, der venter på mere dybtborende undersøgelser, dels på synteseplan, dels på lokalt niveau. 
Litteraturliste

\section{Utrykt:}

Nachtegall, V. F. (1840), Kortfattet Fremstilling af min Virksomhed for Gymnastikkens Indforelse og Udbredelse fra den forste Begyndelse $i$ Aaret 1799 indtil Udgangen af Aaret, KB. NKS 1361 fol.

\section{Trykt:}

Boisen, P. O. (1800), Betragtninger over vigtige Optrin i det huslige Liv (København).

Dragehjelm, Hans (1933), 'Den første Legeplads i Danmark' i Gymnastisk Tidsskrift.

Gjøde Nielsen, Henrik (1994), Sportens spor. Gymnastik- og idratshistorie fra Viborg Amt (Viborg).

Hansen, Jørn (1995), 'Sports- og idrætsfester' i Else Trangbæk, Jørn Hansen og Niels Kayser Nielsen (red.), Dansk idratsliv, bd. 1: Den moderne idrats gennembrud 1860-1940 (København).

Holgaard Rasmussen, Chr. (1979), 'Vesterborg Seminarium' i LollandFalsters Historiske Samfunds Arbog.

Holmgaard, Jens (1986), 'Eksercitsen bag kirken efter gudstjenesten. Var landmilitsen i stavnsbåndstiden en ringe byrde?' i Bol og By, nr. 1 .

Høybye-Nielsen, Ernst (1969), 'Den indbyrdes undervisning i den sjællandske almueskole' i Arbog for Dansk Skolehistorie.

Jensen, C. Gotlieb (1968), Vejle Amts Skytte-, Gymnastik- og Idratsforening 1868-1968 (Vejle).

Jørgensen, Per (1995a), 'Dansk Idræts-Forbunds dannelse' i Else Trangbæk, Jørn Hansen og Niels Kayser Nielsen (red.), Dansk idrcetsliv, bd. 1: Den moderne idrats gennembrud 1860-1940 (København). Jørgensen, Per (1995b), 'Idrættens struktur' i Else Trangbæk, Jørn Hansen og Niels Kayser Nielsen (red.), Dansk idratsliv, bd. 1: Den moderne idrats gennembrud 1860-1940 (København).

Kaae, Alfred (1998) Hover (Hover Borgerforening).

Kayser Nielsen, Niels (1989a), 'Idræt og offentlig støtte - set i et civilisationsperspektiv' i Fortid og Nutid, vol. 36, nr. 3.

Kayser Nielsen, Niels (1989b), 'Pengene eller livet - om offentlig støtte til skyttebevægelsen i 1800-tallet' i Jørn Hansen m. fl. (red.), Idratshistorisk Arbog.

Kayser Nielsen, Niels (1993), Krop og oplysning. Om kropskultur $i$ 
Danmark 1780-1900, (Odense).

Kayser Nielsen, Niels (1995), 'Mellem filantropi og militær - kropskultur og idrætspædagogik i Danmark ca. 1780-1820' i Fund og Forskning $i$ Det Kongelige Biblioteks Samlinger (København).

Kayser Nielsen, Niels (1997), 'Skyttebevægelsen i Trekantområdet' i Idratshistorisk Arbog.

Kayser Nielsen, Niels (2003), 'Kroppens dannelse og dannelsens krop' i Rune Slagstad, Ove Korsgaard og Lars Løvlie (red.), Dannelsens forvandlinger (Oslo).

Krogh, L. F. C. (1911), Skyttesagen i Danmark (København).

Larsen, Joakim (1913), 'Gymnastikundervisningens Indførelse i vore Folkeskoler for 100 Aar siden' i Gymnastisk Selskabs Aarsskrift (København).

Mellemgaard, Signe (1995), 'Den daglige fare' i Folk og Kultur (København).

Mellemgaard, Signe og Niels Kayser Nielsen (1996), 'Kropskultur mellem det internationale og det lokale' i John T. Lauridsen og Margit Mogensen (red.), Kobenhavn - Porten til Europa (København).

Mønster, P. H. (1803), Om Svomme-Øvelser og deres Fremgang hos os som Indbydelse til offentlige Øvelser, hvorved Det gymnastiske Institut hoitideligholder sin forste Olympiade eller fierde Aarsfest (København). KB. 17,-283 40.

Nachtegall, V.F. (1828), Laerebog i Gymnastik (København).

Nachtegall, V.F. (1831), Gymnastikkens Fremgang i Danmark fra dens forste Indforelse i Aaret 1799 indtil Udgangen af Aaret 1830' (København).

Nørr, Erik (1994), Skolen, prasten og kommunen (København).

Pedersen, Henning og Peter Kjeldsen (1993), Store Brønderslev Marked gennem 150 år (Brønderslev).

Peitersen, Birger (1973), 'Ludvig Reventlow og almuens undervisning i 1780'erne' i Arbog for Skolehistorie.

Reventlow, Chr. B. (1902), En dansk Statsmands Hjem omkring 1800, bd. 1. (København).

Reventlow, J. L. (1900), 'Pro Memoria af 30. juni' i Joakim Larsen, 'Pædagogiske Afhandlinger af L. Reventlow. Til Opdragelsens Historie. Aktstykker til Opdragelsens Historie 1' i Vor Ungdom, Tillæg 1899-1900 (København).

Stenius, Henrik (1993), 'Den politiska kulturen i Nordens ontologi. Modell eller icke? Vara eller icke vara?' i Godelieve Laureys, Niels Kayser Nielsen og Johs. Nørregaard Frandsen (red.), Skan- 
dinaviensbilleder. En antologi fra en europaisk kulturkonference (Groningen og Gent).

Svendsen, S. A. (1943), Vejle Amts Skytte-, Gymnastik- og Idratsforening 1918-1943 (Vejle Amts Skytte-, Gymnastik- og Idrætsforenings bestyrelse), (udg.).

Villaume, Peter (1802), 'Om Legemets Dannelse med Hensyn til Menneskets Fuldkommenhed og Lyksalighed, eller om den physiske Opdragelse i Særdeleshed' i J. H. Campe (red.), Revisionsvark, det hele Skole- og Opdragelsesvaesen angaaende, bd. 8 (København). 